\title{
ANALISIS BIAYA PRODUKSI \\ TERHADAP PEMBUATAN MINYAK GORENG DI DUSUN TALOLO KABUPATEN POLEWALI MANDAR
}

\section{Analysis Cost Production Against Maked Fried Oil Located In Hamlet Talolo Districk Tinambung Polewali Mandar}

\author{
Nuraeni M \\ Email: nuraeni@unsulbar.ac.id \\ Prodi Akuntansi Fakultas Ekonomi Unsulbar \\ J1.Prof. Baharuddin Lopa, S Talumung Majene Sulawesi Barat \\ Rasadiah \\ Email: malik12@gmail.com
}

\begin{abstract}
ABSTRAK
Penelitian ini bertujuan : Untuk mengetahui perhitungan biaya produksi Minyak Goreng Mandar. Objek Penelitian adalah usaha kecil pembuat minyak mandar (pattana' minna') yang terletak di Dusun Talolo Kecamatan Tinambung Kabupaten Polewali Mandar. Model penelitian ini terdiri dari beberapa metode dalam menentukan harga pokok produksi yaitu dengan menggunakan pendekatan full costing dan variabel costing sebagai alat analisisnya. Hasil penelitian ini menunjukkan bahwa : Pembuat minyak dalam menentukan harga jual tidak menggunakan perhitungan yang sesuai dengan aturan akuntansi yang ada.
\end{abstract}

Kata Kunci: analisis biaya produksi; full costing; variable costing.

\begin{abstract}
This study aims : to find out the costing production of Mandar oil (Minna' Mandar). The object of research is an small businesses " maker mandar oil " located in the Hamlet Talolo, Districk Tinambung, Polewali Mandar. The research model consists of using costing methods in the cost of goods production namely with approach full costing and variable costing as a tool analysis. The results showed that : maker oil in determining of sold price does not made costing with the rule accounting which exists.
\end{abstract}

Keywords: $\quad$ analysis cost production; oil making. 


\section{PENDAHULUAN}

Indonesia sangat terkenal dengan masakannya yang kaya akan rempah-rempah dan bahan lain. Etnis Mandar, Sulawesi Barat sebagai bagian dari Indonesia sudah tentu juga memiliki berbagai resep masakan yang khas seperti Minna' Mandar. Minna' Mandar memiliki aroma yang khas yang membedakan dengan minyak produksi yang lain. Proses pembuatannya pun masih sangat tradisional di daerah Mandar. Selain dari aromanya yang khas Minna' Mandar juga memiliki daya tahan yang cukup lama hingga 12 bulan bahkan lebih sekalipun tidak menggunakan bahan pengawet kimia sintetik. Selain itu, Minna' Mandar banyak digunakan dalam kehidupan sehari-hari bukan sekedar memasak saja, tapi terkadang juga digunakan sebagai minyak rambut, pelumas, minyak gosok, dan lain-lain.

Jika berbicara mengenai harga minyak goreng dipasaran terkhusus minyak goreng mandar yang diproduksi oleh orang mandar sendiri termasuk di Dusun Talolo, Kecamatan Tinambung, Kabupaten Polewali Mandar Sulawesi Barat. Perlu kita ketahui bahwa, masyarakat di Dusun Talolo kurang memahami bagaimana menentukan harga barang produksinya (minyak goreng). Secara umum masyarakat Dusun Talolo dalam menentukan harga hanya sebatas melihat harga pasar padahal, perlu diketahui dalam menentukan harga selain dari melihat harga pasar, perlu kita ketahui pula berapa biaya-biaya yang telah dikeluarkan dalam mendukung produksi minyak goreng tersebut, baik dari segi bahan bakunya yaitu kelapa, bahan bakar yang digunakan seperti kayu bakar juga termasuk dalam hitungan biaya yang dikeluarkan, sedangkan peralatan yang digunakan dalam proses produksi juga memiliki nilai yang harus dimasukkan dalam biaya yang dikeluarkan dalam proses poduksi minyak mandar. Dalam hal ini penulis melihat para Pattana' Minna' tidak memperhitungkan biaya bahan bakunya, misalnya saja bahan bakunya yaitu kelapa, boleh dikatakan dalam memperolehnya cukup mudah dari segi harganya yang terbilang murah bahkan dapat diperoleh tanpa menggunakan biaya karena didapatkan dari hasil kebun maupun dari hasil upah memanjat pohon kelapa orang lain.

Menurut Mulyadi (2007:16) Biaya adalah pengurangan aktiva netto akibat digunakannya jasa-jasa ekonomis untuk menciptakan pendapatan atau karena pengenaan pajak oleh badan-badan pemerintah. Biaya dihitung menurut jumlah penggunaan aktiva dan pertambahan kewajiban yang berkaitan dengan produksi dan pengiriman barang serta pemberian jasa. Dalam arti yang terluas, beban mencakup semua biaya yang telah habis pakai (expired) yang dapat dikurangkan dari pendapatan. Menurut Standar Akuntansi Keuangan (SAK) Indonesia 2009:Par.6. Istilah beban dapat dinyatakan sebagai biaya yang secara 
langsung atau tidak langsung telah dimanfaatkan didalam usaha menghasilkan pendapatan dalam satu periode, atau yang sudah tidak memberikan manfaat ekonomis untuk kegiatan masa berikutnya. Menurut Sugiarto dkk (2007:15) produksi adalah suatu kegiatan yang mengubah input menjadi output. Kegiatan tersebut dalam ekonomi biasa dinyatakan dalam fungsi produksi. Fungsi produksi menunjukkan jumlah maksimum output yang dapat dihasilkan dari pemakaian sejumlah input dengan menggunakan teknologi tertentu.

Menurut Bustami dan Nurlela (2008:40) penentuan harga pokok adalah bagaimana memperhitungkan biaya kepada suatu produk atau pesanan atau jasa, yang dapat dilakukan dengan cara memasukkan seluruh biaya produksi atau hanya memasukkan unsur biaya produksi variabel saja. Harga pokok produksi pada dasarnya menunjukkan harga pokok produk (barang dan jasa) yang diproduksikan dalam suatu periode akuntansi tertentu. Hal ini berarti bahwa harga pokok produksi merupakan bagian dari harga pokok. Harga pokok produksi atau disebut harga pokok adalah pengorbanan sumber ekonomi yang diukur dalam satuan uang yang telah terjadi atau kemungkinan terjadi untuk memperoleh penghasilan (Mulyadi, 2009:26).

Harga Minna’ Mandar pun sempat berfluktuasi pada tahun 2013 ketika, harga minyak goreng di Indonesia naik. Sempat menembus angka Rp. 12.000,- per botol (sekitar $600 \mathrm{ml}$ ) kini kembali ke kisaran harga Rp. 10.000,- pada tingkat pengecer di daerah Sulawesi Barat. Polewali Mandar merupakan salah satu penghasil Minyak Goreng dari Kelapa. Minyak ini diolah dengan cara tradisional yang bertujuan untuk mempertahankan kualitas minyak. Minyak ini mempunyai ciri khas pada wangi yang dikeluarkan. Untuk beberapa makanan tradisional, minyak ini merupakan salah satu resep tambahan yang ada. Misalnya saja pada pembuatan "Bau piapi" (ikan masak). Oleh sebab itu, melalui penelitian ini penulis ingin mengetahui selama ini seberapa besar biaya yang dikeluarkan dalam proses pembuatan minyak goreng mulai dari bahan-bahan yang diperlukan sampai barang itu menjadi minyak goreng. Selain itu, penulis berharap masyarakat di Dusun Talolo maupun desa lainnya dapat mengetahui cara menentukan harga minyak goreng. Adapun rumusan masalah yang akan dibahas yaitu, apakah perhitungan biaya yang dikeluarkan dalam memproduksi Minna' Mandar telah tepat. Berdasarkan rumusan masalah di atas, adapun tujuan yang ingin dicapai yaitu, untuk mengetahui perhitungan biaya produksi Minyak Goreng Mandar (Minna’ Mandar).

\section{METODE PENELITIAN}

Penelitian ini dilaksanakan di Dusun Talolo Kecamatan Tinambung Kabupaten Polewali Mandar dengan waktu penelitian selama 1 bulan yaitu pada bulan Mei 2016. Adapun populasi penelitian Minna' Mandar adalah Masyarakat pembuat minyak di Dusun Talolo 
Kecamatan Tinambung Kabupaten Polewali Mandar yang berjumlah 4 orang yang membuat minyak. Sampelnya diambil berdasarkan pada masyarakat yang terjun langsung ke usaha pembuatan minyak (pattana' minna') berjumlah 4 orang.

Metode analisis data merupakan upaya untuk mengelola data dengan cara mempelajari permasalahan dan cara untuk mengatasinya. Analisa yang digunakan dalam penentuan HPP adalah dengan menggunakan pendekatan full costing dan variable costing.

1. Pendekatan full costing

Full costing adalah penentuan harga pokok produksi yang memperhitungkan semua unsur biaya produksi yang terdiri dari biaya bahan baku, biaya tenaga kerja dan biaya overhead pabrik baik yang variable maupun tetap.

Cara perhitungan HPP dengan metode Full Costing:

Biaya bahan baku

Rp. $x x x$

Biaya tenaga kerja langsung

Rp. $x x x$

Biaya overhead pabrik variable Rp. $x x x$

Biaya overhead pabrik tetap Rp. $x x x+$

Harga pokok produksi

Rp. $x x x$

2. Pendekatan variable costing

Variable costing adalah suatu konsep penentuan harga pokok produksi yang hanya memasukkan atau membebankan biaya produksi variable sebagai elemen harga pokok produksi, sedangkan biaya produksi tetap dianggap sebagai biaya periode yang langsung dibebankan kepada laba rugi.

Cara perhitungan HPP dengan metode variabel costing adalah:

Biaya bahan baku Rp. $\mathrm{xxx}$

Biaya tenaga kerja langsung Rp. $x x x$

Biaya overhead pabrik variable $\underline{\text { Rp. } x x x}$

Harga pokok produksi

Rp. $x x x$

3. Penentuan harga jual

Harga jual = taksiran biaya penuh + laba yang diharapkan

Harga jual per unit = biaya yang berhubungan langsung dengan volume (per unit) + persentase markup.

Laba yang diharapkan + biaya yang tidak dipengaruhi langsung oleh volume produksi

Persentase markup $=$

Biaya yang dipengaruhi langsung oleh volume produksi 


\section{HASIL DAN PEMBAHASAN}

\section{Perhitungan Biaya Pembuatan Minyak Menurut Pattana’ Minna'}

Adapun analisis pencatatan biaya pembuatan minyak di Dusun Talolo menurut pattana' minna' sendiri dalam penentuan harga pokok produksi jika menggunakan metode full costing dan variabel costing adalah sebagai berikut:

1. Biaya bahan baku

Bahan baku yang digunakan untuk membuat minyak mandar adalah hanya kelapa yang cukup tersedia untuk diperoleh walaupun pembuat minyak tidak membeli kelapa dengan kata lain tidak mengeluarkan biaya.

2. Biaya tenaga kerja langsung

Pada usaha pembuatan minyak ini tenaga kerja yang digunakan adalah pemilik usaha sendiri bersama istrinya. Pembuatan minyak ini tidaklah membutuhkan keterampilan khusus hanya dibutuhkan seseorang yang mampu bekerja keras karena pada tahap pembuatannya memerlukan tenaga untuk memeras sampai mengaduk santan didalam api sampai selesai.

3. Biaya overhead pabrik

Biaya overhead pabrik pada usaha pembuatan minyak yaitu ongkos pabrik kelapa yang merupakan biaya overhead variabel, sebagai berikut : Jumlah kelapa 150 buah menghasilkan $60 \mathrm{~kg}$ isi daging kelapa dan ongkos kelapa per 10kg kelapa $=$ Rp. 3.000. Jadi 60kg kelapa x Rp. 3.000,- = Rp. 18.000, ongkos pabrik kelapa : Rp. 18.000,- / 24 = Rp. 750 ,-

Tabel 1. Kalkulasi Harga Pokok Produksi Minyak Mandar Dengan Metoode Full Costing

\begin{tabular}{|c|l|c|}
\hline No & \multicolumn{1}{|c|}{ Jenis biaya produksi } & Biaya per botol \\
\hline 1 & Biaya bahan baku: Kelapa & Rp. 0,- \\
\hline 2 & Biaya tenaga kerja langsung & Rp. 0,- \\
\hline 3 & $\begin{array}{c}\text { Biaya overhead variabel } \\
-\quad \text { Ongkos pabrik }\end{array}$ & Rp. 750,- \\
\hline & Harga pokok produksi perbotol & Rp. 750,- \\
\hline
\end{tabular}




\section{Analisis Biaya Produksi dan Perhitungan Biaya Produksi Minyak Goreng Mandar}

\section{a. Pengelompokan Biaya Menurut Akuntansi}

1. Biaya bahan baku

Bahan baku yang digunakan untuk membuat minyak mandar adalah kelapa. Jumlah kelapa yang biasa mereka produksi untuk membuat minyak berjumlah 150 buah untuk menghasilkan 24 botol minyak berukuran $600 \mathrm{ml}$ perbotol atau setara dengan 3 jerigen minyak berukuran 5 liter. Sebagaimana pada saat ini diketahui bahwa harga kelapa perbuah sebesar Rp. 2.500,- untuk ukuran yang besar. Berikut unsur-unsur biaya yang dikeluarkan:

Kelapa 150 buah@x Rp. 2.500,-=Rp.375.000,-

Jumlah produksi : 1 kali@ 3 jerigen=3 jerigen

1 jerigen $=8$ botol

Jadi 3 × $8=24$ botol

Biaya bahan baku per botol adalah = Rp. 375.000,- / Rp. $24=$ Rp.15.625,-

2. Biaya tenaga kerja langsung

Jika memasukkan biaya tenaga kerja langsung dalam perhitungan sesuai metode yang digunakan untuk menentukan harga jual maka biaya yang biasa diberikan untuk tenaga kerja langsung sebesar Rp. 10.000,-. Adapun unsur-unsur biaya tenaga kerja langsung adalah sebagai berikut:

Upah tenaga kerja : Rp. $10.000 \times 1$ kali produksi $=$ Rp. 10.000

Jumlah tenaga kerja $=2 \times$ Rp. $10.000=$ Rp. 20.000

Jumlah produksi 24 botol per hari

Biaya tenaga kerja per botol adalah :

Tenaga kerja = Rp. $20.000 / 24=$ Rp. $833,-$

3. Biaya overhead pabrik

Jenis-jenis biaya overhead yang dapat diidentifikasi dalam penelitian ini adalah:

1) Biaya overhead variabel

- Ongkos pabrik kelapa

Jumlah kelapa yang diproduksi sekitar 150 buah menghasilkan $60 \mathrm{~kg}$ isi daging kelapa dan ongkos kelapa per $10 \mathrm{~kg}=\mathrm{Rp}$. 3.000,

Jadi 60kg kelapa x Rp. 3.000,- = Rp. 18.000 , maka biaya overhead variabel = Rp. 18.000,- / 24 = Rp. 750,-

2) Biaya overhead tetap

- Biaya penyusutan peralatan 
Untuk menghitung biaya penyusutan maka perlu diketahui harga perolehan dan taksiran umur ekonomis dari peralatan dengan menggunakan metode garis lurus. Adapun jenis dan umur peralatan yang digunakan adalah sebagai berikut:

Tabel 2. Jenis Dan Umur Peralatan Pembuatan Minyak

\begin{tabular}{|c|l|c|c|}
\hline No & \multicolumn{1}{|c|}{ Jenis Peralatan } & Umur & Harga \\
\hline 1 & Wajan & 3 tahun & Rp. 170.000 \\
\hline 2 & Linggis atau Passukkeang & 5 tahun & Rp. 100.000 \\
\hline 3 & Pa'epeang & 20 tahun & Rp. 500.000 \\
\hline
\end{tabular}

Jumlah produksi yang telah dihasilkan dalam kapasitas normal adalah 24 botol jadi nilai penyusutan peralatan ini adalah sebagai berikut:

1. Wajan $=$ Rp. $170.000,-: 3$ tahun $=$ Rp. $56.666,67: 12$ bulan $=$ Rp. $4.722,23$

$$
=\text { Rp. } 4.722,23: 24=\text { Rp. } 196,76
$$

Jadi biaya penyusutan peralatan wajan adalah sebesar Rp.196,76

2. Linggis atau Passukkeang $=$ Rp. 100.000,- : 5 tahun $=$ Rp. 20.000,- : 12 bulan

$$
=\text { Rp. } 1.666,67=\text { Rp. } 1.666,67: 24=\text { Rp. } 69,45
$$

Jadi biaya penyusutan linggis atau passukkeang adalah sebesar Rp. 69,45

3. Pa'epeang $=$ Rp. 500.000,- : 20 tahun $=$ Rp. 25.000,- : 12 bulan $=$ Rp. 2083,33

$$
=\text { Rp. } 2083,33: 24=\text { Rp. } 86,81
$$

Jadi biaya penyusutan pa'epeang adalah sebesar Rp.86,81

Jumlah total penyusutan $=$ Rp. $196,76+$ Rp. $69,45+$ Rp. $86,81=$ Rp. 363,02

\section{b. Perhitungan Biaya dengan Metode Full Costing dan Variable Costing}

Berdasarkan hasil pengklasifikasian biaya produksi sebelumnya maka berikut akan dilakukan perhitungan harga pokok produksi dengan menggunakan metode full costing dan variable costing sebagai berikut:

1. Penentuan Harga Pokok Produksi Metode Full Costing 
Tabel 3. Kalkulasi Harga Pokok Produksi Dengan Metoode Full Costing

\begin{tabular}{|c|c|c|}
\hline No & Jenis biaya produksi & Biaya per botol \\
\hline 1 & $\begin{array}{c}\text { Biaya bahan baku } \\
\text { - Kelapa }\end{array}$ & Rp. 15.625,- \\
\hline 2 & Biaya tenaga kerja langsung & Rp. 833,- \\
\hline 3 & $\begin{array}{l}\text { Biaya overhead } \\
\begin{array}{l}\text { a. Biaya overhead variabel } \\
\text { - Ongkos pabrik } \\
\text { b. Biaya overhead tetap } \\
\text { - Biaya penyusutan } \\
\text { Jumlah biaya overhead }\end{array}\end{array}$ & $\begin{array}{l}\text { Rp. } 750,- \\
\text { Rp. } 363,02 \\
\text { Rp. } 1103,02\end{array}$ \\
\hline & Harga pokok produksi perbotol & Rp. 17.571,02 \\
\hline
\end{tabular}

2. Penentuan Harga Pokok Produksi Metode Variabel Costing

Tabel 4. Kalkulasi Harga Pokok Produksi Dengan Metoode Full Costing

\begin{tabular}{|c|l|c|}
\hline No & Jenis Biaya Produksi & Biaya perbotol \\
\hline 1 & $\begin{array}{c}\text { Biaya bahan baku } \\
-\quad \text { Kelapa }\end{array}$ & Rp. 15.625,- \\
\hline 2 & $\begin{array}{r}\text { Biaya tenaga kerja langsung } \\
-\quad \text { Tenaga kerja langsung }\end{array}$ & Rp. 833,- \\
\hline 3 & $\begin{array}{r}\text { Biaya overhead } \\
\text { a. Biaya overhead variabel }\end{array}$ & Rp. 750,- \\
\hline & Harga pokok produksi perbotol & Rp. 17.208,- \\
\hline
\end{tabular}

\section{c. Evaluasi Perhitungan Harga Pokok Produksi}

Berikut adalah hasil evaluasi perhitungan harga pokok produksi dengan mengunakan dua metode yaitu full costing dan variable costing : 
Tabel 5. Evaluasi Perhitungan Harga Pokok Produksi Minyak Mandar

\begin{tabular}{|c|c|c|c|}
\hline No & Jenis biaya produksi & Full costing & Variable costing \\
\hline 1 & $\begin{array}{l}\text { Biaya bahan baku } \\
\text { - Kelapa }\end{array}$ & Rp. 15.625,- & Rp. 15.625,- \\
\hline 2 & Biaya tenaga kerja langsung & Rp. 833,- & Rp. 833,- \\
\hline 3 & $\begin{array}{l}\text { Biaya overhead } \\
\text { a. Biaya overhead variabel } \\
\bullet \quad \text { Ongkos pabrik } \\
\text { b. Biaya overhead tetap } \\
\text { • Biaya penyusutan } \\
\text { Jumlah biaya overhead }\end{array}$ & $\begin{array}{l}\text { Rp. } 750,- \\
\text { Rp. } 363,02 \\
\text { Rp. } 1113,02\end{array}$ & $\begin{array}{l}\text { Rp. } 750,- \\
\text { Rp. } 750,-\end{array}$ \\
\hline & $\begin{array}{l}\text { Harga pokok produksi } \\
\text { perbotol }\end{array}$ & Rp. 17.571, 02 & Rp. 17.208,- \\
\hline
\end{tabular}

\section{d. Implikasi Perhitungan Terhadap Laba dan Penentuan Harga Jual} Metode Full costing

Laporan Laba-Rugi Usaha kecil Dusun Talolo Periode 1 bulan Tahun 2016

Penjualan

Harga pokok penjualan

Marjin bruto

Persentase mark up

$$
\begin{array}{ll}
\text { (24 x Rp. 18.000) } & \text { Rp. 432.000,- } \\
(24 \times \text { Rp. 17.571,02) } & \text { Rp. 421.704,48 } \\
& \text { Rp. } 10.295,52 \\
\text { Marjin Bruto } & \text { Rp. } 10.295,52
\end{array}
$$

$$
\begin{aligned}
& \text { Harga pokok penjualan } \quad \text { Rp. } 421.704,48 \\
& =\text { Rp. } 0,024 \text { atau } 0,02 \%
\end{aligned}
$$

\section{Metode Variabel costing}

\section{Laporan Laba Rugi \\ Usaha kecil Dusun Talolo \\ Periode 1 bulan}

$\begin{array}{lll}\text { Penjualan } & (24 \text { x Rp. 18.000) } & \text { Rp. 432.000,- } \\ \text { Harga pokok penjualan } & (24 \text { x Rp. 17.208,- }) & \text { Rp. 412.992,- }\end{array}$ 
Marjin bruto

Rp. 19.008,-

$$
\begin{array}{lll}
\text { Prosentase mark up } & =\frac{\text { Marjin Bruto }}{\text { Harga pokok penjualan }}=\frac{\text { Rp. 19.008,- }}{\text { Rp. 412.992,- }} \\
& =\text { Rp. 0,046 atau 0,04\% }
\end{array}
$$

\section{Penentuan Harga Jual}

Penentuan harga jual full costing dengan metode cost plus, yaitu:

Tabel 6. Perhitungan harga jual dengan Cost Plus Pricing berdasarkan pendekatan Full Costing

\begin{tabular}{|l|l|l|}
\hline Bahan baku langsung & Rp. 15.625,- & \\
\hline Tenaga kerja langsung & Rp. 833,- & \\
\hline Biaya overhead variabel & Rp. 750,- & \\
\hline Biaya overhead tetap & Rp. 363,02 & \\
\hline Total Biaya Produksi & & Rp. 17.571,02 \\
\hline Mark up (0,02\% x Rp. 17.571,02) & & Rp. 35,12 \\
\hline Harga jual & & Rp. 17.606,14 \\
\hline
\end{tabular}

Penentuan harga jual variabel costing dengan metode cost plus, yaitu:

Tabel 7. Perhitungan Harga Jual Dengan Cost Plus Pricing Berdasarkan

Pendekatan Variabel Costing

\begin{tabular}{|l|l|l|}
\hline Bahan baku langsung & Rp. 15.625,- & \\
\hline Tenaga kerja langsung & Rp. 833,- & \\
\hline Biaya overhead variabel & Rp. 750,- & \\
\hline Total Biaya Produksi & & Rp. 17.208,- \\
\hline Mark up (0,04\% x Rp. 17.208,-) & & Rp. 6,88 \\
\hline Harga jual & & Rp. $17.214,9$ \\
\hline
\end{tabular}

Berdasarkan perhitungan harga pokok produksi di atas kita dapat melihat hasil yang didapatkan dari pendekatan full costing yaitu sebesar $0,02 \%$ dan variabel costing sebesar $0,04 \%$. 


\section{KESIMPULAN DAN SARAN}

Berdasarkan hasil analisis data dari hasil penelitian dapat disimpulkan sebagai berikut:

1. Pembuat minyak dalam menentukan harga jual belum menggunakan perhitungan yang sesuai dengan aturan akuntansi yang ada.

2. Biaya tidak dicatat berdasarkan teori akuntansi yang ada, sehingga pembuat minyak tidak memperhitungkan beberapa biaya lainnya, yang seharusnya dimasukkan dalam biaya produksi.

3. Hasil perhitungan harga pokok produksi minyak mandar dapat menjadi pedoman dalam mengambil keputusan bagi para pembuat minyak.

Sedangkan saran-saran yang dapat penulis berikan dalam rangka mencapai tujuan usaha adalah sebagai berikut:

1. Penelitian ini dapat membantu para pembuat minyak (pattana' minna') untuk menentukan harga jual minyak mereka sesuai dengan perhitungan akuntansi agar tidak rugi.

2. Sebaiknya pembuat minyak (pattana' minna') dalam menentukan harga pokok penjualan menggunakan perhitungan yang sesuai dengan perhitungan akuntansi yang ada agar, tidak menentukan harga jual sesuai dengan biaya bahan baku saja seperti yang berlaku selama ini.

\section{DAFTAR PUSTAKA}

Arifin Zainal. 2011. Evaluasi Pembelajaran Prinsip, Teknik, Prosedur. Bandung : PT Remaja Rosdakarya.

Bustami, Bastian dan Nurlela. 2008. Akuntansi Biaya. Jakarta : Mitra Wacana Media

Dunia, Firdaus Ahmad dan Wasilah, 2009, Akuntansi Biaya. Edisi 2, Jakarta: Salemba Empat.

Ikatan Akuntan Indonesia. 2009. Standar Akuntansi Keuangan. Jakarta :

Salemba Empat

Mulyadi, 2007. Akuntansi Biaya. Yogyakarta : BPFE-UGM

Muhammad Ali, Hamzah. 2011. Analisis Strategi Pemasaran Minyak Kelapa Sawit (Crude Palm Oil) Pada PT.Kharisma Pemasaran Bersama Nusantara Jakarta.

Nirwanto, Rasditya. 2011. Analisis Penentuan Harga Pokok Produksi Kopi Pada Tingkat Petani Kopi Di Kecamatan Kembang Kabupaten Bondowoso.

Sugiyono. 2011. Metode Penelitian Pendidikan (Pendekatan Kuantitatif, kualitatif, dan $R \& D)$. bandung : Alfabeta

Usry, Carter. 2004. Akuntansi Biaya, buku 1, Thomson Learning, dialih bahasakan oleh Krista. Jakarta : Salemba Empat.

Yamit, Sulian, 2005, Manajemen Produksi dan Operasi. Jakarta:Bumi Aksara 